гогіка та психологія. - Харків: Вид-во ТОВ «Щедра садиба плюс», 2015. - Вип. 48. - 260 с.

7. Муздыбаев, К. Психология ответственности [Текст] / К. Муздыбаев. - Л.: Наука, 1983. - 240 с.

8. Берталанфи, Л. фон. Общая теория систем - критический обзор [Текст] / Л. фон Берталанфи; общ. ред. В. Н. Садовского, Э. Г. Юдина // Исследования по общейтеории систем. - М.: Прогресс, 1969. - С. 23-82.

9. Уёмов, А. И. Системныйподход и общаятеория систем [Текст] / А. И. Уемов. - М.: Мысль, 1978. - 272 с.

10. Ильина, Т. А. Системно-структурный подход к организации обучения [Текст] / Т. А. Ильина. - М.: Знание, 1972. $-72 \mathrm{c}$.

11. Методы системного педагогическогоисследования [Текст] / под ред. Н. В. Кузьминой. - Л.: Изд-во Ленингр. ун-та, 1980. $-172 \mathrm{c}$.

12. Анохин, П. К. Узловые вопросы теории функциональных систем [Текст] / П. К. Анохин. - М.: Наука, 1980. -435 c.

13. Андреєва, М. О. Розвиток соціальної компетентності студентів 3 особливими потребами у вищому навчальному закладі [Текст]: автореф. дис. ... канд. пед. наук / М. О. Андреєва; Державний вищий навчальний заклад „Донбаський державний педагогічний університет”. Слов'янськ, 2013. - 22 с.

14. Чернецька, Ю. І. Теорія і практика соціальнопедагогічної роботи з ресоціалізації наркозалежних в умовах реабілітаційних центрів [Текст]: автореф. дис. ... д-ра пед. наук / Ю. І.Чернецька; Державний заклад „Луганський національний університет імені Тараса Шевченка”. - Старобільськ, 2016. - $46 \mathrm{c}$.

\section{References}

1. Osokina, Ju. S. (2006). Vidpovidal'nist' social'nogo sub'jekta: filosofs'kyj analiz. Kyiv, 24.
2. Lynovyc'ka, O. (2011). Sociokul'turna vidpovidal'nist' osvity. Kyiv: Vyd-vo NPU imeni M. P. Dragomanova, 19.

3. Radchenko, O. V., Savchenko, I. G. (2008). Cinnisnyj vymir social'noi' vidpovidal'nosti v demokratychnij derzhavi. Kharkiv: Vyd-vo HNUVS, 200.

4. Vasjanovych, G. P. (2002). Moral'no-pravova vidpovidal'nist' pedagoga (teoretyko-metodologichnyj aspekt). Lviv: Vyd-vo «SPOLOM», 232.

5. Mal'ko, A. M., Vasylenko, O. M. (2004). Social'nopedagogichna dijal'nist' u zakladah osvity. Kharkiv: Krok, 83.

6. Vasylenko, O. M. (2015). Social'na vidpovidal'nist' u dysertacijnyh doslidzhennjah social'no-pedagogichnoi' sprjamovanosti. Pedagogika ta psyhologija. Kharkiv: Vyd-vo TOV «Shhedra sadyba pljus», 48, 260.

7. Muzdybaev, K. (1983). Psihologija otvetstvennosti. Leningrad: Nauka, 240.

8. Bertalanfi, L. fon.; Sadovskogii, V. N., Judin, Je. G. (Eds.) (1969). Obshhaja teorija sistem - kriticheskij obzor. Issledovanija po obshhejteorii sistem. Moscow: Progress, 23-82.

9. Ujomov, A. I. (1978). Sistemnyjpodhod i obshhajateorija sistem. Moscwo: Mysl', 272.

10. Il'ina, T. A. (1972). Sistemno-strukturnyj podhod k organizacii obuchenija. Moscow: Znanie, 72.

11. Kuz'mina, N. V. (Ed.) (1980). Metody sistemnogo pedagogicheskogoissledovanija. Leningrad: Izd-vo Leningr. un-ta, 172.

12. Anohin, P. K. (1980). Uzlovye voprosy teorii funkcional'nyh sistem. Moscow: Nauka, 435.

13. Andrejeva, M. O. (2013). Rozvytok social'noi' kompetentnosti studentiv z osoblyvymy potrebamy u vyshhomu navchal'nomu zakladi. Slovjans'k, 22.

14. Chernec'ka, Ju. I. (2016). Teorija i praktyka social'no-pedagogichnoi' roboty $\mathrm{z}$ resocializacii' narkozalezhnyh v umovah reabilitacijnyh centriv. Starobil's'k, 46.

Рекомендовано до публікації д-р пед. наук, професор Подберезський М. К. Дата надходження рукопису 05.07.2016

Василенко Ольга Миколаївна, кандидат педагогічних наук, доцент, кафедра соціальної педагогіки, Харківський національний педагогічний університет імені Г. С. Сковороди, вул. Алчевських, 29, м. Харків, Україна, 61002

E-mail: o_vas@ukr.net

\title{
UDC 378
}

\section{ISTOTA I PERSPEKTYWY STOSOWANIA PODEJŚCIA AKMEOLOGICZNEGI W PROCESIE KSZTALTOWANIA PODMIOTOWOŚCI ZAWODOWEJ PRZYSZLYCH FILOLOGÓW}

\section{(C) N. Aristova}

W artykule uzasadniono konieczność stosowania podejścia akmeologicznego do ksztaltowania podmiotowości zawodowej przyszłych filologów na uczelniach Ukrainy. Stwierdzono, że stosowanie podejścia akmeologicznego umożliwia badania regularności akmeologicznego rozwoju osobowości, przyczynia się do ksztaltowania u studentów-filologów pozytywnego i twórczego stosunku do siebie i do innych, gotowości do osiagnięcia wyżyn profesjonalizmu w przyszłej pracy zawodowej, a także zapewnia ksztaltowanie ich podmiotowości zawodowej. $\mathrm{Na}$ podstawie analizy prac współczesnych badaczy autorka wyjaśnia istotę kluczowych pojęć podejścia akmeologicznego, mianowicie: „akme”, „profesjonalizm”, „zawodowiec”, „regularności akmeologiczne”, „,zasada dialogowości”, , aktywność osobowości”

Stowa kluczowe: podejście akmeologiczne, profesjonalizm, podmiotowość zawodowa, przyszli filolodzy, aktywność osobowości, zasady nauczania, metody nauczania, metody badawcze, środowisko akmeologiczne, uczelnia 
The paper specifies the essence and prospects of implementing acmeological approach into the process of formation of future filologists' professional subjectness. It is found out that implementing acmeological approach into the educational space enables the study of patterns of person's acmeological development, facilitates the formation of students' positive and creative attitude towards themselves as well as professional subjectness, readiness to succeed in their future career. The author considers training principles and methods of the acmeological approach. The meanings of the concepts ,acme”, „professionalism”, „professional”, „, acmeological patterns”, ,principle of dialogueness”, ,person's activity” which are the key concepts of the acmeological approach based on the analysis of present-day scientists' research are specified in the article

Keywords: acmeological approach, professionalism, professional subjectness, future philologists, person's activity, training principles, training methods, research methods, acmeological environment, higher educational establishment

\section{Wprowadzenie}

Zapotrzebowanie współczesnego społeczeństwa ukraińskiego na wszechstronnie rozwiniętych filologów, którzy są gotowi do ciągłego samodoskonalenia, samorozwoju i samorealizacji w swojej przyszłej pracy zawodowej, wymaga znalezienia optymalnego zestawu metodologicznych podejść do kształtowania podmiotowości zawodowej przyszłych fachowców. Teoretyczna analiza literatury naukowej i edukacyjnej wskazuje na istnienie wielu tradycyjnych i innowacyjnych podejść metodologicznych, których stosowanie w procesie edukacyjnym na współczesnych uniwersytetach jest koniecznym i niepodważalnym warunkiem doskonalenia kształcenia przyszłych specjalistów. Wśród metod, które odgrywają ważną rolę w kształtowaniu podmiotowości zawodowej przyszłych filologów, podejście akmeologiczne zajmuje szczególne miejsce. Podejście akmeologiczne zajmuje szczególne miejsce wśród podejść metodologicznych, które odgrywają ważną rolę $\mathrm{w}$ kształtowaniu podmiotowości zawodowej przyszłych filologów. Może ono być stosowane w procesie edukacyjnym ze względu na to, że akmeologia umożliwia badanie osobowości przyszłych filologów jako integralnego zjawiska w jedności ich istotnych postaci (osoba, osobowość, podmiot działalności ludzkiej, indywidualność) [1]. Wobec tego aktualność tematu badawczego nie budzi wątpliwości, ponieważ takie podejście zapewnia doskonałą okazję do kształcenia wysoko wykwalifikowanych filologów, do ich samorealizacji w przyszłej pracy zawodowej oraz do wzbogacenia kulturowego $\mathrm{i}$ duchowego.

\section{Analiza najnowszych badań i publikacji} naukowych, określenie problemu badawczego

Teoretyczne podstawy stosowania podejścia akmeologicznego do kształtowania podmiotowości zawodowej przyszłych filologów stanowią prace współczesnych badaczy krajowych i zagranicznych, w tym S. Akimowa [2], O. Akimowej [3], A. Antonowej [1], H. Biriukowej [4], A. Derkacza [5], O. Dubaseniuk [6], T. Zobninej [4], I. Nikołajesku [7, 8], O. Susłowej [9]. Wybór prac wyżej wymienionych naukowców jest podyktowany tym, że w nauce ukraińskiej kwestia stosowania podejścia akmeologicznego jako podstawy metodologicznej kształtowania podmiotowości zawodowej dotychczas nie została wyczerpująco zbadana. Najwięcej uwagi kwestii wdrożenia podejścia akmeologicznego w proces edukacji wyższej poświęcili naukowcy rosyjscy, w tym S. Akimow [2], O. Akimowa [3], H. Biriukowa [4], A. Derkacz [5], T. Zobnina [4] oraz O. Susłowa [9]. Wobec tego w niniejszym artykule powołujemy się przeważnie na ich badania naukowe. Ponadto warto dodać, że badacze ukraińscy i badacze rosyjscy są zgodni co do tego, że podejście akmeologiczne jest jednym $\mathrm{z}$ najbardziej postępujących i perspektywicznych podejść dla współczesnego systemu szkolnictwa wyższego, gdyż stosowanie tego podejścia do edukacji umożliwia badanie regularności osiągnięcia wyżyn profesjonalizmu i regularności twórczego rozwoju osobowości przyszłego zawodowca oraz promuje potrzebę wzbogacania i aktualizacji wiedzy i kompetencji zawodowych.

\section{Cel badań}

Aktualność problemu i jego niedostateczne zbadanie pozwoliły na określenie celu opracowania, którym jest teoretyczne uzasadnienie konieczności stosowania podejścia akmeologicznego do kształtowania podmiotowości zawodowej przyszłych filologów na uczelniach Ukrainy. Aby osiągnąc ten cel, wykonano następujące zadania:

- dokonano analizy struktury podejścia akmeologicznego;

- wyjaśniono istotę kluczowych pojęć podejścia akmeologicznego na podstawie analizy prac współczesnych badaczy;

- określono perspektywy stosowania podejścia akmeologicznego do kształtowania podmiotowości zawodowej przyszłych filologów na uczelniach Ukrainy.

\section{Podstawa materiałowa i metody badań}

$\mathrm{W}$ celu przeprowadzenia badania korzystano $\mathrm{z}$ następujących metod badawczych: $\mathrm{z}$ teoretyczno-metodologicznej analizy literatury psychologicznej i pedagogicznej, co pozwoliło na uzasadnienie konieczności stosowania podejścia akmeologicznego do kształtowania podmiotowości zawodowej przyszłych filologów na uczelniach Ukrainy; $\mathrm{z}$ analizy pojęciowej $\mathrm{i}$ terminologicznej, która pozwoliła na wyodrębnienie i uzasadnienie aparatu pojęciowego i kategorialnego opracowania; z refleksji dyskusyjnej, która pozwoliła na skonstruowanie wniosków opartych na logicznej formie rozumowania.

\section{Wyniki badań}

Warto podkreślić, że akmeologia jako nauka ma długą historię. Jest ona oparta na ideach starożytnych uczonych, którzy uważali, że głównym celem rozwoju każdego człowieka jest osiągnięcie najwyższego stopnia samodoskonalenia. Tak więc w roku 144 p.n.e. 
starożytny grecki filozof Apollodoros, który był przedstawicielem szkoły aleksandryjskiej i uczniem Diogenesa z Seleucji, wprowadził do obiegu naukowego łaciński termin ,acme” rozumiany przez niego jako najwyższy punkt rozwoju osoby będący kulminacją działań. Kulminacja działań, zdaniem myśliciela, i jest stanem, w którym dana osoba osiąga wyższy stopień samodoskonalenia, czyli ,akme" $[1,10]$.

Powstanie i rozwój współczesnej akmeologii są związane z pracami M. Rybnikowa, B. Ananjewa, O. Bodałewa i N. Kuźminej, którzy definiowali ją jako naukę kompleksowo badającą rozwój dorosłej osoby [3]. Tę definicję przyjmują również współcześni badacze, którzy określają akmeologię jako naukę badającą regularności i sposoby ewentualnego ujawnienia przez osobę własnego potencjału oraz osiągania na tej podstawie najlepszych wyników w swoim rozwoju pozytywnym jako osoby i osobowości, podmiotu i indywidualności - jako zintegrowanego wielowymiarowego człowieka - w specjalnie zorganizowanym procesie edukacyjnym [3]. Od początku istnienia akmeologia jako nauka nie tylko opracowuje strategie i technologie kształtowania wysoko wykwalifikowanych specjalistów w każdej branży, nie tylko pozwala zidentyfikować najlepsze warunki nauczania, wprowadzenie których w proces edukacyjny pomaga przyszłemu specjaliście zrealizować siebie jako osobowość i podmiot działalności, ale również zapewnia udane doskonalenie i samodoskonalenie osobowości, jej pełną samorealizację w przyszłej pracy zawodowej i w życiu w ogóle [3]. Według wielu naukowców jedną z kluczowych kwestii współczesnej akmeologii jest kwestia kształtowania i rozwoju ludzkiej kreatywności w różnych formach działalności zawodowej. Podstawowy obszar badań akmeologii jest związany z badaniem profesjonalizmu jako wyższego stopnia rozwoju osobowości, jego obiektem jest ,profesjonalizm edukacyjnej, medycznej, inżynieryjnej, wojskowej i innej działalności osobowości” [11], przedmiotem zaś - „czynniki obiektywne (regularności w organizacji szkolenia specjalistów, wpływające na jakość kształcenia) i subiektywne (talent, zdolności osobiste), które przyczyniają się do osiągnięcia wyżyn profesjonalizmu" [11]. Dlatego głównym zadaniem akmeologii w zakresie szkolnictwa wyższego jest opracowanie narzędzi samodoskonalenia i rozwoju działalności ludzkiej przyszłych zawodowców w celu osiągnięcia wyższego poziomu umiejętności zawodowych [5].

Aby zrozumieć konieczność stosowania podejścia akmeologicznego do procesu kształtowania podmiotowości zawodowej przyszłych filologów, należy szczegółowo przyjrzeć się jego strukturze, która składa się z trzech elementów, mianowicie $\mathrm{z}$ pojęć, zasad i metod nauczania.

Główne pojęcia podejścia akmeologicznego stanowią: „akmeologiczny rozwój osobowości”, „,profesjonalizm”, „zawodowiec”, „kreatywność”, ,akme”, „regularności akmeologiczne”, ,aktywność osobowości”, „akmeologiczne technologii pedagogiczne”, ,indywidualne, osobiste i podmiotowe cechy” oraz „dojrzałość” i „dojrzałość akademicka” $[6,7]$.
Tak więc, zdaniem wielu naukowców, „profesjonalizm działalności” jest cechą osoby, która dąży do „akme” lub do wyżyn doskonałości w zawodzie, a termin „akme” (z greckiego ACME - wyżyna, czas kwitnienia) oznacza „najwyższy poziom osiągnięć w rozwiązywaniu konkretnych problemów i zadań w każdym zawodzie, w tym w nauce, sztuce, literaturze, technice, edukacji” [7]. Wobec tego można stwierdzić, że profesjonalizm osoby przejawia się nie tylko w osiąganiu wysokich wyników i wysokiej wydajności pracy, ale również w posiadaniu całości psychologicznych elementów wewnętrznego stosunku osoby do pracy, czyli pewien stan jej cech psychicznych. W związku z tym podczas analizy profesjonalizmu należy wyodrębniać dwa stany, w tym stan obszaru motywacyjnego działalności zawodowej osoby i stan obszaru operacyjnego działalności zawodowej [12]. Biorąc pod uwagę to, że głównym przejawem profesjonalizmu na poziomie obszaru motywacyjnego osoby jest jej pragnienie rozwoju jako zawodowca, wykorzystywanie każdej okazji do rozwoju zawodowego i twórczej samorea-lizacji, badanie stanu obszaru motywacyjnego działalności zawodowej specjalistów pozwala naukowcom zrozumieć, co pobudza osobę, jakie cele ona chce osiągnąć i w jakim stopniu jest zadowolona $\mathrm{z}$ wyników swojej pracy [12]. Z kolei badanie obszaru operacyjnego działalności zawodowej umożliwia zrozumienie tego, jakich technik używają ludzie do osiągnięcia celów oraz jakiej wiedzy, jakich operacji myślenia, zdolności i technologii potrzebują do wykonywania swoich obowiązków zawodowych ze względu na to, że głównymi przejawami profesjonalizmu na poziomie operacyjnym są: ukształtowana świadomość zawodowa, wysoka wydajność pracy, niezawodność i stabilność wysokiej wydajności, a także przekształcenie środowiska zawodowego [12].

Według opinii P. Pidkasystego i N. Kołesniczenki $\mathrm{W}$ sprawie istoty profesjonalizmu, z którymi się zgadzamy, profesjonalizm przyszłych filologów jest specjalnym systemem, który składa się z dwóch połączonych ze sobą podsystemów: profesjonalizmu zawodowego i profesjonalizmu osobistego. Zatem profesjonalizm działalności przyszłego filologa jest jego cechą jakościową, która odzwierciedla jego wysokie kwalifikacje zawodowe i kompetencje, obecność ważnych umiejętności zawodowych oraz posiadanie nowoczesnych metod rozwiązywania zadań zawodowych, co umożliwia prowadzenie działalności zawodo-wej o wysokiej wydajności [12]. Profesjonalizm osobowości przyszłego filologa jest również jego cechą jakościową, która odzwierciedla wysoki poziom jego kreatywności, zawodowo ważnych i osobowych cech,właściwy poziom roszczeń i orientacje wartościowe [13].

Typową jest definicja ,zawodowca” jako ,,przedmiotu działalności zawodowej, który posiada wysoki wskaźnik profesjonalizmu osobowości i działalności, który ma wysoki status zawodowy i społeczny, dynamicznie rozwinięty system osobistej i zawodowej regulacji normatywnej, nieustannie koncentruje się na samorozwoju i samodoskonaleniu, na społecznie pozytywnych osiągnięciach osobistych i zawodowych" [6]. Wobec tej definicji przyszły filolog jako zawodowiec ma 
wysoki poziom profesjonalizmu zawodowego i osobistego, dynamicznie rozwinięty system regulacji osobowej mającej na celu samorozwój i samodoskonalenie oraz osiągnięcia osobiste i zawodowe, które przyczyniają się do uzyskania określonego statusu zawodowego i społecznego [13].

Osiągnięcie przez przyszłych specjalistów wysokiej wydajności w działalności zawodowej zależy od ich aktywności, rozumianej przez współczesnych naukowców jako „ludzka zdolność do świadomego działania zawodowego i społecznego, celowe i systematyczne przekształcenie otoczenia i samego siebie w oparciu o wiedzę z zakresu kultury materialnej i duchowej" [7]. Ze względu na to, że działalność jednostki widoczna jest przede wszystkim w kreatywności, aktach wolicjonalnych i komunikacyjnych, integralna cecha tego pojęcia przejawia się w aktywnej postawie życiowej przyszłych zawodowców, w podejmowaniu przez nich inicjatyw, w przestrzeganiu zasad i konsekwentnej obronie swoich przekonań; „kreatywność” należy rozpatrywać jako najwyższą formę aktywności przyszłych zawodowców [7].

Współcześni badacze za poszczególne cechy przyszłych zawodowców uważają stan ludzkiego ciała jako całości, stan poszczególnych organów i ich funkcjonowanie w porównaniu z normą, za cechy osobowe stosunek osoby do różnych aspektów rzeczywistości, za subiektywne - ,wszystkie cechy, od których zależy wykonywanie przez osobę czynności" [5].

Jako dojrzałość domyślnie rozumiemy „najdłuższy okres ontogenezy, który charakteryzuje się tendencją do osiągnięcia największego rozwoju duchowych, intelektualnych i fizycznych zdolności osoby" [7]. Przy określaniu charakteru pojęcia „dojrzałość akademicka” zgadzamy się z T. Olchową, która uważa, że jest to „zdolność do harmonijnego i niezależnego działania mającego na celu realizację systemu wartości, który spełnia oczekiwania społeczeństwa... Dojrzałość akademicka zawiera zestaw cech studenta, pozwalający mu wykazać się jako obywatel, osobowość, podmiot działalności, nosiciel indywidualnych, osobistych, podmiotowychi aktywnych właściwości i cech" [14]. Badaczka słusznie dodaje, że zestaw wartości, które definiują dojrzałość akademicką studentów, zależy od dwóch czynników, w tym od uczelni i od środowiska [14].

Kolejną centralną kategorię podejścia akmeologicznego, którego istotę zamierzamy ujawnić, stanowią regularności akmeologiczne. We współczesnej pedagogice regularności akmeologiczne są rozpatrywane jako stabilne połączenia między poziomem wydajności pracy pojedynczych osób lub zintegrowanych grup i społeczności zawodowych, $\mathrm{z}$ jednej strony, i z czynnikami (obiektywnymi, subiektywnymi i subiektywno-objektywnymi) przyczyniającymi się do osiągania wysokich wyników (wyżyn), z drugiej [7].

Należy dodać, że realizacja podejścia akmeologicznego w edukacji winna opierać się na akmeologicznych technologiach edukacyjnych i metodach organizacji działań edukacyjnych i występować w warunkach środowiska akmeologicznego. Wprowadzenie akmeologicznych technologii edukacyjnych do kształtowania podmiotowości zawodowej przyszłych filologów promuje nie tylko rozwój własnych zdolności, ale również osiągnięcie jak najlepszych możliwych wyników dzięki wysiłkom wszystkich zawodowców zajmujących się pedagogicznym wsparciem studentów [5]. Do uznanych technik edukacyjnych współcześni badacze zaliczają: technikę projektowania życia i samorozwoju, technikę wyszukiwania problemów, technikę wydajnego nauczania, technikę rozwoju osobistego oraz działania ludzkiego itp. [2, 6-8]. Metody organizacji działania edukacyjnego w ramach podejścia akmeologiczne-go to: metoda „okrągłego stołu”, metoda ,work-shop”, metoda gier symulacyjnych i metoda,,problem-based learning".

Akmeologiczne podejście do kształtowania podmiotowości zawodowej przyszłych filologów, jak każde inne podejście metodologiczne, jest realizowane na podstawie pewnych zasad, w tym humanizacji, demokratyzacji, ciągłości, fundamentalizacji, indywidualizacji, systemowości, dialogowości [6] oraz zasad rozwoju człowieka w trakcie osiągania wyżyn profesjonalizmu [4]. Zasada humanizacji przejawia się $\mathrm{W}$ humanistycznej orientacji procesu edukacyjnego na uznanie wartości przyszłego filologa jako osobowości, jego prawa do swobodnego rozwoju i tworzenie korzystnych warunków dla przejawu jego umiejętności. Zasada demokratyzacji, która jest określana przez zmiany w życiu publicznym kraju, zapewnia relacje demokratyczne pomiędzy podmiotami nauczania, podczas gdy zasada ciągłości zapewnia integralność i ciągłość wszystkich proceduralnych i systemowych aspektów związanych z procesem edukacyjnym. Według O. Dubaseniuk, zasada fundamentalizacji oznacza orientację procesu edukacyjnego na fundamentalny i interdyscyplinarny charakter wiedzy. Zasada indywidualizacji jest realizowana $w$ procesie edukacyjnym poprzez ustosunkowanie się do osobistych cech i wartości podmiotów nauczania. Zasada dialogowości przewiduje orientację osobyna wartości duchowe i jest oparta na jej wszechstronnym rozwoju, dokonującym się podczas wzajemnego oddziaływania podmiotów nauczania.Treścią tej orientacji jest wymiana określonymi wartościami intelektualnymi, emocjonalnymi i moralnymi [6].

Zasady rozwoju człowieka w osiąganiu wyżyn profesjonalizmu stanowią: zasada podmiotu i podmiotowości, zasada działalności, zasada modelowania, zasada refleksji, zasada przetwarzania potencjalnego w rzeczywiste, zasada optymalności, zasada kształtowania pozytywnej samooceny osobowości [4]. Zasada podmiotu i podmiotowości, która, zdaniem wielu naukowców, ma fundamentalne znaczenie dla akmeologii, oparta jest na uznaniu przedmiotu nie tylko za centrum organizacji życia, ale także podmiotowości, która przejawia się $\mathrm{W}$ potrzebie i ludzkiej zdolności do samodoskonalenia [4]. Potrzeba realizacji zasady działalności, która jest jedną $\mathrm{z}$ podstawowych zasad teorii psychologicznej, jest wywołana definicją działalności jako takiej cechy podmiotu-działacza, która pozwala mu przewidywać przyszłość oraz kontrolować swoje zachowanie podczas osiągania celów [4]. Zasada przetwarzania potencjalnego w rzeczywiste, która jest ściśle związana $\mathrm{z}$ zasadą optymalizacji, przewiduje rozwój wewnętrznych zasobów przyszłych zawodowców. Istotą zasady optymalizacji $\mathrm{z}$ kolei jest zapewnienie korzystnych warunków dla powstawania profesjonalnie 
ważnych cech przyszłego zawodowca [4]. Realizacja zasady refleksji, która dąży do wysokiego poziomu rozwoju samowiedzy przyszłych zawodowców, przebiega poprzez ukierunkowanie studentów na poznanie samych siebie w trakcie studiowaniana uczelni oraz świadomość znaczenia refleksji dla przyszłej działalności zawodowej [4]. Stosowanie zasady kształtowania pozytywnej samooceny polega na zapewnieniu atmosfery pozytywnej interakcji między podmiotami nauczania [4].

Rozwiązywaniu akmeologicznych problemów i zadań w edukacji służą akmeologiczne metody badań przygotowania zawodowego przyszłych specjalistów. Zastosowanie tych metod pozwala wykładowcom określić poziom zawodowego i osobistego rozwoju studentów i wspierać ich rozwój zawodowy do poziomu profesjonalizmu podczas studiów [2]. Główne metody akmeologiczne stanowią: diagnoza akmeologiczna, badanie akmeologiczne i profesjogramy [2]. Diagnoza akmeologiczna jest zwartym systemem, który określa, w jakim stopniu status osobisty i zawodowy danej osoby odpowiada pewnemu modelowi najwyższego rozwoju osoby jako zawodowca i osobowości. Główne składniki diagnozy akmeologicznej to: analiza działalności zawodowej i modelowanie osobistych i profesjonalnych wymagań do zawodowca; określenie poziomu profesjonalizacji jednostki dla organizacji skutecznej przyszłej działalności zawodowej; identyfikacja zawodowych, społecznych i akmeologicznych czynników wpływających na profesjonalizację przyszłych specjalistów oraz rozwój instrumentalnych i metodologicznych narzędzi pomiaru akmeologicznego [9].

Istotą badania akmeologicznego z kolei jest określenie poziomu i warunków podnoszenia profesjonalizmu przyszłych filologów oraz określenie warunków niezbędnych dla rozwoju osobistego i zawodowego w kontekście szkolnictwa wyższego [2].

Warto dodać, że skuteczne nauczanie przyszłych filologów wymaga użycia różnego rodzaju profesjogramów. Tak, profesjogram w szerokim znaczeniu tego słowa jest systematycznym i całościowym opisem charakterystyk zawodu oraz wymagań dotyczących osobliwości indywidualnych i psychologicznych przyszłych zawodowców. W wąskim znaczeniu profesjogram to ,spowodowanyistotą pracy system informacji o społeczno-ekonomicznych, technologicznych, zdrowotnych i pedagogicznych aspektach zawodu, o jego psychologicznych i psycho-fizycznych właściwościach i cechach, które są konieczne i wystarczające do skutecznego opanowania i skutecznego wykonywania określonej działalności zawodowej" [11]. Schemat profesjogramu ma określoną strukturę, która zawiera: ogólny opis zawodu, warunki sanitarno-higieniczne i bezpieczeństwo pracy, wymagania zawodu wobec pracownika, nauka zawodu, przeciwwskazania do nauki i wykonywania obowiązków zawodowych, wynagrodzenia, szkolenia i perspektywy zatrudnienia [11]. Ze względu na to, ze profesjogram powinien być opracowany $\mathrm{w}$ oparciu o systemowe, aktywne i indywidualne podejścia, jego opracowanie opiera się na następujących zasadach: zawodów;
- zasada ukierunkowanego opracowywania profesjogramu, podporządkowanego osiąganiu konkretnych celów;

- zasada wyświetlania typowych cech określonych zawodów;

- zasada prawdziwego wyświetlania zawodu w konkretnych warunkach społeczno-gospodarczych;

- zasada uwzględnienia dynamiki rozwoju zawodu;

- zasada perspektywy rozwoju zawodowego pracownika i kariery;

- zasada obowiązkowego uwzględnienia działań zawodowców w sytuacjach nadzwyczajnych;

- zasada naukowości [11].

Jedną z odmian profesjogramu jest akmeogram, określany przez współczesnych badaczy jako „system wymagań, warunków i czynników, które przyczyniają się do stopniowego rozwoju, a zwłaszcza do rozwoju profesjonalizmu osoby i działalności podmiotów pracy" [7]. Zatem stosowanie niektórych akmeologicznych metod badawczych w przygotowywaniu przyszłych filologów w warunkach podejścia akmeologicznego umożliwia szczegółową analizę i modelowanie systemu organizacji procesu edukacyjnego do kształtowania zawodowej podmiotowości przyszłych filologów oraz określenie sprzyjających warunków do jej realizacji.

Teoretyczna analiza działalności kadry pedagogicznej pozwala twierdzić, że wdrożenie podejścia akmeologicznego $\mathrm{w}$ proces edukacyjny uczelni, którapobudza przyszłych filologów do samorozwoju, samoorganizacji i samodoskonalenia $\mathrm{w}$ ich przyszłej pracy zawodowej, przewiduje podniesienie zawodowych i osobistych cech studentów, organizację specjalnego środowiska akmeologicznego, określenie własnej pozycji akmeologicznej oraz rozwój i realizację własnego potencjału twórczego [8]. Osiąga się to poprzez wprowadzenie niezbędnych warunków psychologicznych i akmeologicznych, w tym tworzenie sytuacji zawodowego i osobistego rozwoju przyszłych filologów, osiągnięcie określonego wyniku wspólnych działań poprzez aktywne współdziałanie wszystkich podmiotów nauczania oraz tworzenie przestrzeni dla rozwoju profesjonalnej refleksji, bowiem profesjonalna refleksja jest jedną $\mathrm{Z}$ najważniejszych cech podmiotowości zawodowej niezbędną do wzajemnego porozumiewania się między zawodowcami w profesjonalnej komunikacji [8].

Naukowe pomysły i prace współczesnych badaczy krajowych i zagranicznych pozwalają na stwierdzenie, że podstawowymi cechami podmiotowości przyszłych filologów w kontekście podejścia akmeologicznego są: wymiary działalności osobowości rozumiane jako ,szybka orientacja (w nowej sytuacji, materiale); świadomość (struktury swojej działalności, cech osobowości, etapów życia); inicjatywa, samodzielne wyznaczanie celów, planowanie i prognozowanie; zaangażowanie w działalność; dążenie do samoregulacji (samokontroli, samodoskonalenia, samokompensacji), posiadanie metod samoregulacji; świadomość sprzeczności własnego rozwoju, ich wyeliminowanie, zapewnienie równowagi i harmonii; stałe dążenie osobowości do samorozwoju i samoodnowy, do samorealizacji i kreatywności; integracja własnego rozwoju zawodowego, strukturyzacja i uporządkowanie własnego doświadczenia zawodowego i doświadczenia innych" [6]. 


\section{Wnioski}

Podsumowując, akmeologiczne podejście do kształtowania podmiotowości zawodowej studentówfilologów na uczelniach Ukrainy może przyczynić się do kształtowania u przyszłych specjalistów pozytywnego i twórczego nastawienia do siebie, do innych, do własnej działalności zawodowej, do rozwoju pewnych cech wewnętrznych, które są niezbędne do jak najpełniejszej samorealizacji zawodowej oraz do osiągnięcia wyżyn własnego profesjonalizmu. Biorąc pod uwagę to, że kształtowanie u przyszłych specjalistów potrzeby samodoskonalenia i aktualizacji ważnej wiedzy zawodowej i ważnych umiejętności zawodowych oraz kształtowanie pragnienia sukcesu zawodowego i osiągnięcia wyżyn profesjonalizmu stanowią obecnie bardzo ważną kwestię, właśnie podejście akmeologiczne może skutecznie pomóc w rozwiązywaniu wyżej wymienionych problemów.

\section{Literatura}

1. Antonova, O. Ye. Akmeolohichnyy pidkhid do vyznachennya sutnosti pedahohichnoyi obdarovanosti [Text]: nauk.-prakt. konf. / O. Ye. Antonova; V. O. Ohnev'yuk (Ed.) // Akmeolohiya - nauka KhKhI stolittya. - Kyyiv: Kyyivs'kyy un-t imeni Borysa Hrinchenka, 2011. - P. 17-22.

2. Akimov, S. S. Primenenie akmeologicheskikh metodov issledovaniya $\mathrm{v}$ professional'noy podgotovke bakalavrov tekhnologicheskogo obrazovaniya [Text] / S. S. Akymov // Molodoy uchenyi. - 2011. - Issue 9. - P. 196-198.

3. Pedagogicheskaya akmeologiya [Text]: kollektyvnaya monografiya / O. B. Akimova (Ed.); FHAOU VPO «Ros. gos. prof-ped. un-t». - Ekaterinburg, 2012. $-251 \mathrm{p}$.

4. Biriukova, H. M. Metodologicheskie printsypy akmeologicheskogo podkhoda $\mathrm{k}$ psikhologicheskoy podgotovke studentov pedagogicheskogo universiteta [Text] / G. M. Biriukova, T. V. Zobnina // Uchenye zapiski universiteta im. P. F. Lesgafta. - 2010. - Vol. 10, Issue 68. - P. 17-23.

5. Akmeologiya [Text] / A. A. Derkach (Ed.). - Moscow: Yzd-vo «RAGS», 2004. - 424 p.

6. Profesiyna pedahohichna osvita: akme-synerhetychnyy pidkhid [Text]: monohrafiya / O. A. Dubaseny-uk (Ed.). Zhytomyr: Vyd-vo ZhDU im. I. Franka, 2011. - 389 p.

7. Akmeolohichnyy slovnyk [Text]. - Cherkasy: OIPOPP, 2012. $-28 \mathrm{p}$.

8. Nikolayesku, I. O. Praktychni osnovy akmeo-lohichnoho rozvytku osobystosti $\mathrm{v}$ umovakh osvitn'o-informa-siynoho prostoru [Text]: navchal'no-metodychnyy posibnyk / I. O. Nikolayesku. - Cherkasy: OIPOPP, 2012. - 98 p.

9. Suslova, E. A. Metodologiya i metody psykhologoakmeologicheskogo issledovaniya [Text]: Uchebnoe posobie / E. A. Suslova; A. A. Derkach (Ed.). - Moscow: Yzd-vo RAGS, 2008. - $158 \mathrm{p}$.

10. Yl'yn, E. P. Psykhologiya vzroslosti [Text] / E. P. Yl'yn. - Sankt-Peteburg: Piter, 2012. - 544 p.

11. Entsyklopediya osvity [Text] / Akadem. ped. nauk Ukrayiny; V. H. Kremin' (Ed.). - Kyyiv: Yurinkom Inter, 2008. - $1040 \mathrm{p}$.

12. Psykhologiya i pedagogika [Text]: uchebnyk dlia vuzov / P. I. Pydkasistii (Ed.). - Moscow: Izdatel'stvo Yurait; Vysshee obrazovanie, 2010. - 714 p.
13. Kolesnychenko, N. Yu. Profesiyna pidhotovka bakalavriv romano-hermans'koyi filolohiyi: analiz kontseptual'nykh zasad problemy [Text] / N. Yu. Ko-lesnychenko // Problemy suchasnoyi pedahohichnoyi osvity. - 2014. - Issue 44. P. 130-137.

14. Ol'khovaya, T. A. Stanovlenie sub'ektnosti studentov universiteta [Text]: dis. ... dokt. ped. nauk / T. A. Ol'khovaya. - Orenbug, 2007. $-430 \mathrm{p}$.

\section{References}

1. Antonova, O. Ye.; Ohnev'yuk, V. O. (Ed.) (2011). Akmeolohichnyy pidkhid do vyznachennya sutnosti pedahohichnoyi obdarovanosti. Akmeolohiya - nauka KhKhI stolittya. Kyiv: Kyyivs'kyy un-t imeni Borysa Hrinchenka, 17-22.

2. Akimov, S. S. (2011). Primenenie akmeologicheskyh metodov issledovaniya $\mathrm{v}$ professional'noi podgotovke bakalavrov tekhnologycheskogo obrazovaniya [The usage of acmeological research methods during professional training of bachelors of technological education]. Young scientist, 9, 196-198.

3. Akimova, O. B. (Ed.) (2012). Pedagogycheskaya akmeologiya [Pedagogical acmeology]. Yekaterinbug, 251.

4. Biriukova, G. M., Zobnina, T. V. (2010). Metodologicheskie printsypy akmeologicheskogo podhoda $\mathrm{k}$ psyhologycheskoi podgotovke studentov pedagogicheskogo universiteta [Methodological principles of acmeological approach to the psychological training of students of pedagogical university]. Scientific proceedings of university named after P. F. Lesgaft, 10 (68), 17-23.

5. Derkach, A. A. (Ed.) (2004). Akmeologiya [Acmeology]. Moscow: «RAGS», 424.

6. Dubasenyuk, O. A. (Ed.) (2011). Profesiyna pedahohichna osvita: akme-synerhetychnyy pidkhid [Professional pedagogical education: acme-synergetic approach]. Zhytomyr: Vyd-vo ZhDU im. I. Franka, 389.

7. Akmeolohichnyy slovnyk [Acmeological dictionary] (2012). Cherkassy: OIPOPP, 28.

8. Nikolayesku, I. O. (2012). Praktychni osnovy akmeolohichnoho rozvytku osobystosti $\mathrm{v}$ umovakh osvitn'oinformatsiynoho prostoru [Practical bases of acmeological development of personality in terms of educational and informative space]. Cherkassy: OIPOPP, 98.

9. Suslova, E. A.; Derkach, A. A. (Ed.) (2008). Metodologiya i metody psyhologo-akmeologicheskogo issledovaniya [Methodology and methods of psychological and acmeological research]. Moscow: Izd-vo RAGS, 158.

10. Yl'yn, E. P. (2012). Psykhologiya vzroslosti [Psychology of adulthood]. Saint-Petersburg: Piter, 544.

11. Kremin' V. H. (Ed.) (2008). Entsyklopediya osvity [Encyclopedia of education]. Kyiv: Yurinkom Inter, 1040.

12. Pidkasistyi P. I. (Ed.) (2010). Psykhologiya i pedagogika [Psychology and pedagogics]. Moscow: Izdatel'stvo Yurait; Vysshee obrazovanie, 714.

13. Kolesnychenko, N. Yu. (2014). Profesiyna pidhotovka bakalavriv romano-hermans'koyi filolohiyi: analiz kontseptual'nykh zasad problemy [Professional training of bachelors of Romance and Germanic phylology: analysis of conceptual bases of the problem]. Problems of present-day pedagogical education, 44, 13-137.

14. Ol'hovaia, T. A. (2007). Stanovlenie sub'ektnosti studentov universiteta [Formation of subjectness of university students]. Orenburg, 430.

Рекомендовано до публікаџії д-р пед. наук Малихін О. В. Дата надходження рукопису 14.07.2016

Aristova Nataliia, Candidate of Pedagogic Sciences, associate professor, Department of Romance and Germanic languages and Translation, National University of Life and Environmental Sciences of Ukraine, Heroyiv Oborony str., 15, Kyiv, Ukraine, 03041

E-mail: ydzu@meta.ua 